NASA/TM—2010-216773

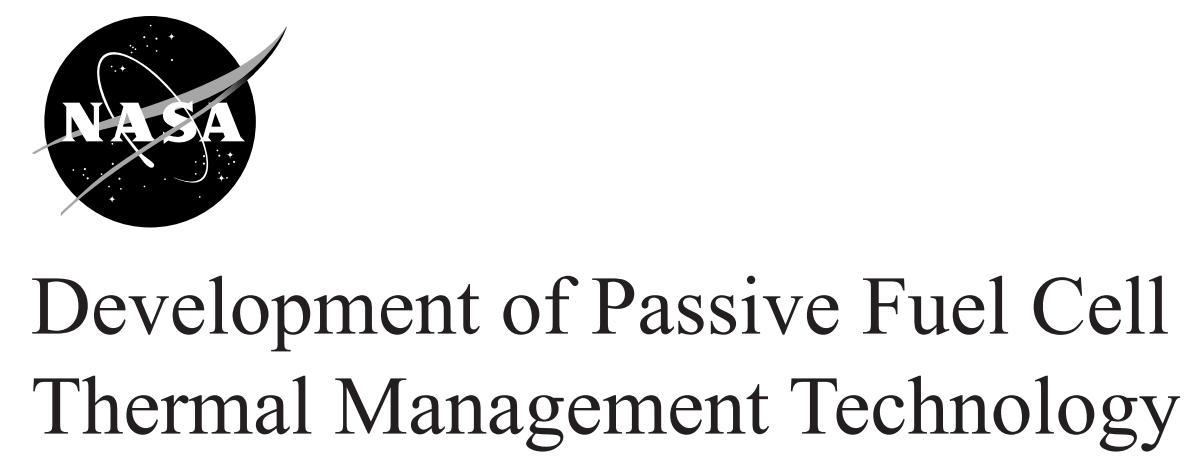

Kenneth A. Burke

Glenn Research Center, Cleveland, Ohio

Ian Jakupca and Anthony Colozza

Analex Corporation, Brook Park, Ohio 


\section{NASA STI Program . . . in Profile}

Since its founding, NASA has been dedicated to the advancement of aeronautics and space science. The NASA Scientific and Technical Information (STI) program plays a key part in helping NASA maintain this important role.

The NASA STI Program operates under the auspices of the Agency Chief Information Officer. It collects, organizes, provides for archiving, and disseminates NASA's STI. The NASA STI program provides access to the NASA Aeronautics and Space Database and its public interface, the NASA Technical Reports Server, thus providing one of the largest collections of aeronautical and space science STI in the world. Results are published in both non-NASA channels and by NASA in the NASA STI Report Series, which includes the following report types:

- TECHNICAL PUBLICATION. Reports of completed research or a major significant phase of research that present the results of NASA programs and include extensive data or theoretical analysis. Includes compilations of significant scientific and technical data and information deemed to be of continuing reference value. NASA counterpart of peer-reviewed formal professional papers but has less stringent limitations on manuscript length and extent of graphic presentations.

- TECHNICAL MEMORANDUM. Scientific and technical findings that are preliminary or of specialized interest, e.g., quick release reports, working papers, and bibliographies that contain minimal annotation. Does not contain extensive analysis.

- CONTRACTOR REPORT. Scientific and technical findings by NASA-sponsored contractors and grantees.
- CONFERENCE PUBLICATION. Collected papers from scientific and technical conferences, symposia, seminars, or other meetings sponsored or cosponsored by NASA.

- SPECIAL PUBLICATION. Scientific, technical, or historical information from NASA programs, projects, and missions, often concerned with subjects having substantial public interest.

- TECHNICAL TRANSLATION. Englishlanguage translations of foreign scientific and technical material pertinent to NASA's mission.

Specialized services also include creating custom thesauri, building customized databases, organizing and publishing research results.

For more information about the NASA STI program, see the following:

- Access the NASA STI program home page at http://www.sti.nasa.gov

- E-mail your question via the Internet to help@ sti.nasa.gov

- Fax your question to the NASA STI Help Desk at 443-757-5803

- Telephone the NASA STI Help Desk at 443-757-5802

- Write to: NASA Center for AeroSpace Information (CASI) 7115 Standard Drive Hanover, MD 21076-1320 
NASA/TM-2010-216773

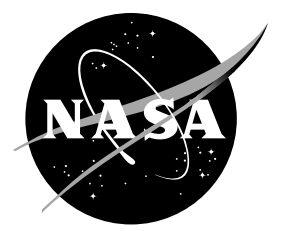

\section{Development of Passive Fuel Cell Thermal Management Technology}

Kenneth A. Burke

Glenn Research Center, Cleveland, Ohio

Ian Jakupca and Anthony Colozza

Analex Corporation, Brook Park, Ohio

Prepared for the

Seventh International Energy Conversion Engineering Conference (IECEC)

sponsored by the American Institute of Aeronautics and Astronautics

Denver, Colorado, August 2-5, 2009

National Aeronautics and

Space Administration

Glenn Research Center

Cleveland, Ohio 44135 
Trade names and trademarks are used in this report for identification only. Their usage does not constitute an official endorsement, either expressed or implied, by the National Aeronautics and Space Administration.

Level of Review: This material has been technically reviewed by technical management.

Available from

NASA Center for Aerospace Information 7115 Standard Drive

Hanover, MD 21076-1320
National Technical Information Service 5301 Shawnee Road Alexandria, VA 22312

Available electronically at http://gltrs.grc.nasa.gov 


\title{
Development of Passive Fuel Cell Thermal Management Technology
}

\author{
Kenneth A. Burke \\ National Aeronautics and Space Administration \\ Glenn Research Center \\ Cleveland, Ohio 44135 \\ Ian Jakupca and Anthony Colozza \\ Analex Corporation \\ Brook Park, Ohio 44142
}

\begin{abstract}
The NASA Glenn Research Center is developing advanced passive thermal management technology to reduce the mass and improve the reliability of space fuel cell systems for the NASA exploration program. The passive thermal management system relies on heat conduction within the cooling plate to move the heat from the central portion of the cell stack out to the edges of the fuel cell stack rather than using a pumped loop cooling system to convectively remove the heat. Using the passive approach eliminates the need for a coolant pump and other cooling loop components which reduces fuel cell system mass and improves overall system reliability. Previous analysis had identified that low density, ultra-high thermal conductivity materials would be needed for the cooling plates in order to achieve the desired reductions in mass and the highly uniform thermal heat sink for each cell within a fuel cell stack (Ref. 1). A pyrolytic graphite material was identified and fabricated into a thin plate using different methods. Also a development project with Thermacore, Inc. resulted in a planar heat pipe. Thermal conductivity tests were done using these materials. The results indicated that lightweight passive fuel cell cooling is feasible.
\end{abstract}

\section{Introduction}

The purpose of this work was to test sample potential cooling plates for NASA's fuel cells. The key parameters used to screen these samples were thermal conductivity, material density, and compatibility with the anticipated fuel cell stack environment. Materials that demonstrated sufficient promise as passive cooling plates would continue to be studied and further optimized with the goal of developing a light weight fuel cell cooling plate.

\section{Nomenclature}

A Cooling plate cross sectional area, $\mathrm{m}^{2}$

$\mathrm{dT} / \mathrm{dx}$ Temperature gradient, $\mathrm{K} / \mathrm{m}$

k Thermal conductivity, Watt/m-K

Q Applied heat, W

$\mathrm{T}$ Cooling plate temperature, $\mathrm{K}$

$\mathrm{x}$ Location of the temperature measurement on the cooling plate, $\mathrm{m}$

\section{Background}

The heart of a fuel cell is an electrochemical "cell" that combines a fuel and an oxidizing agent, and converts the chemical energy directly into electrical power, water, and waste heat. The fuel cells used by NASA are hydrogen-oxygen fuel cells. The fuel cells under development for future NASA missions are acid-based Proton Exchange Membrane (PEM) hydrogen-oxygen fuel cells. An illustration of this type of cell is shown in Figure 1. A hydrogen molecule reacts at the anode to create a pair of protons and electrons. The proton ion exchange membrane conducts the protons which were generated at the anode from the anode to the cathode. The electrons which were also generated at the anode are conducted through the electrical load that is connected to the fuel cell and also reach the cathode. The hydrogen protons and the electrons are reacted at the cathode with an oxygen atom to produce a molecule of water. An illustration of a "stack" of cells connected electrically in series shown in Figure 1. 

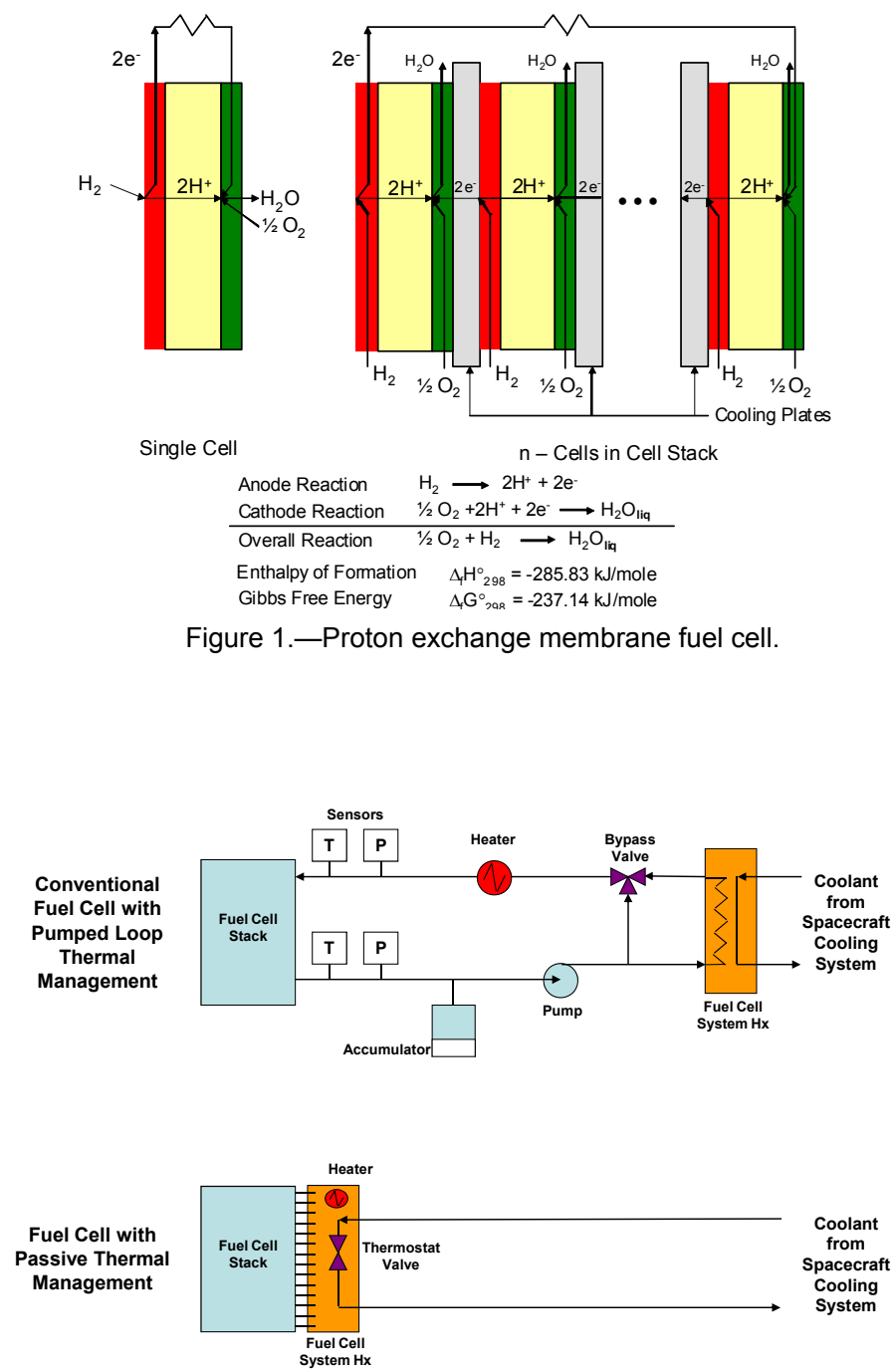

Figure 2.-Fuel cell thermal management systems.

Heat must be removed from the fuel cell stack to prevent the stack from overheating. Heat is typically removed from the fuel cells via cooling plates within the fuel cell stack that are located between the cells as shown in Figure 1. Typically a liquid coolant is circulated within the plate and heat is removed convectively as the coolant passes through each cooling plate and out of the fuel cell stack to a fuel cell system heat exchanger. A passive cooling plate must conduct the heat within the plane of the plate out to one or more of the edges of the plate so that the heat can be transferred to a heat exchanger external to the fuel cell stack. Figure 2 shows the difference between a conventional fuel cell thermal management system and a passive fuel cell thermal management system. Potential benefits of the passive approach include reductions in mass, system complexity, and parasitic power as well as improvements in system reliability.

Figure 3 plots the fuel cell heat generation density (the heat generated per unit of cell area) versus the fuel cell output current density (Ref. 1). NASA's fuel cell applications typically optimize in the lower current density range $\left(\leq 400 \mathrm{~mA} / \mathrm{cm}^{2}\right)$, so the heat generation expected from NASA's fuel cells is generally $\leq 0.3 \mathrm{Watt} / \mathrm{cm}^{2}$.

The key to making the passive approach workable is making the cooling plates light enough yet highly thermally conductive so that the heat can be effectively removed and also provide each cell in the fuel cell stack a thermally uniform heat sink. Analytical expressions were developed (Ref. 1) that relate the thermal performance of a passive cooling plate to its physical characteristics. There are two key metrics used in the evaluation of the thermal management system, the first is the maximum temperature difference, the $\Delta \mathrm{T}$, over the chemically active area of each cell in the fuel cell stack. Ideally, a uniform temperature over the active area is desired because this maximizes the electrochemical performance throughout the stack. In practice, a $\Delta \mathrm{T}$ of zero is never achieved because the 


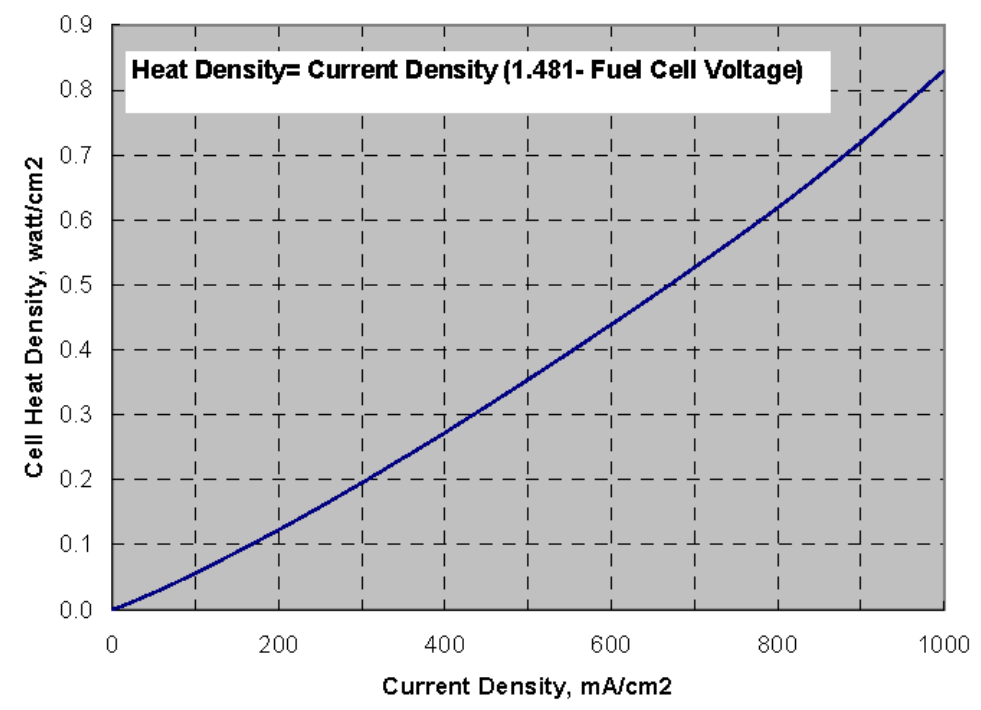

Figure 3.-Fuel cell heat generation.

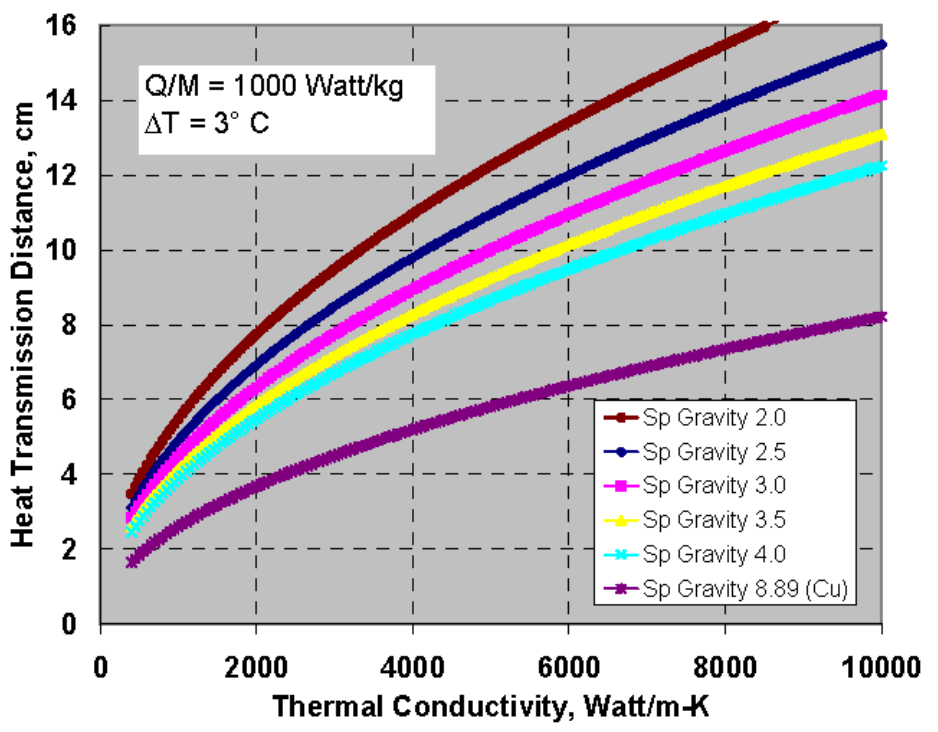

Figure 4.-Cooling plate heat transmission distance, thermal conductivity, and plate specific gravity.

process of removing waste heat from the fuel cell always requires a temperature differential. In practice, a $\Delta \mathrm{T}$ of $3{ }^{\circ} \mathrm{C}$ has been acceptable, and therefore was used as a driving requirement. A second key metric is the mass of the thermal management system. The waste heat managed per unit mass of the thermal management system was the defined metric for mass evaluation. The thermal system mass was considered to be the mass of the cooling plates internal to the fuel cell stack and the mass of thermal system components external to the fuel cell stack such as the coolant, cooling lines, pump, accumulator, sensors, etc. The mass of the fuel cell system heat exchanger common to both approaches was excluded from the mass of the thermal system. The space shuttle fuel cell powerplant has a maximum heat rejection of $7322 \mathrm{~W}$ and an overall mass of $115.7 \mathrm{~kg}$ (Ref. 2). The fraction of the overall shuttle fuel cell powerplant mass represented by the thermal system was not known but estimated to be 10 percent. This would result in a waste heat per unit mass of $633 \mathrm{~W} / \mathrm{kg}$. A value of $1000 \mathrm{~W} / \mathrm{kg}$ was used as a goal for the passive thermal management system.

Using the $1000 \mathrm{~W} / \mathrm{kg}$ as the value of the metric, and $3^{\circ} \mathrm{C}$ as the $\Delta \mathrm{T}$, the relationship between heat transmission distance, $\mathrm{L}$, the specific gravity of the cooling plate, $\rho$, and the thermal conductivity, $\mathrm{k}$ of the cooling plate is plotted in Figure 4 using the analytical relationships developed (Ref. 1).

From the plot shown in Figure 4, it is apparent that for fuel cells which have to transmit the heat $\geq 4 \mathrm{~cm}$, a thermal conductivity of $\geq 1000 \mathrm{~W} / \mathrm{m} / \mathrm{K}$ and a specific gravity of $\leq 4 \mathrm{gm} / \mathrm{cc}$ would be required to meet the metric targets. 


\section{Advanced Cooling Plate Materials}

Table 1 lists candidate high thermally conductive materials (Ref. 3). These alternative materials are all carbon based: diamond, diamond composites, pyrolytic graphite, and graphite composites. Highly Oriented Pyrolytic Graphite (HOPG) has the best combination of high thermal conductivity and low specific gravity. HOPG appears to meet the criteria if the heat transmission distance is less than $7 \mathrm{~cm}$.

TABLE 1.-PASSIVE COOLING PLATE MATERIALS (REF. 3)

\begin{tabular}{|l|c|c|}
\hline \multicolumn{1}{|c|}{ Material } & $\begin{array}{c}\text { Thermal conductivity, } \\
\text { Watt } / \mathrm{m}-\mathrm{K}\end{array}$ & $\begin{array}{c}\text { Specific gravity, } \\
\mathrm{g} / \mathrm{cm}^{3}\end{array}$ \\
\hline CVD diamond & 1100 to 1800 & 3.5 \\
\hline HOPG & ${ }^{\mathrm{a}} 1500$ to 1700 & 2.3 \\
\hline Natural graphite & 500 & ---------- \\
\hline Cont. CF/Cu & ${ }^{\mathrm{a}} 400$ to 420 & 5.3 to 8.2 \\
\hline Carbon/carbon & ${ }^{\mathrm{a}} 400(690)$ & 1.9 \\
\hline Gr Flake/Al & ${ }^{\mathrm{a}} 400$ to 600 & 2.3 \\
\hline Diamond/Cu & 600 to 1200 & 5.9 \\
\hline Diamond/Al & 550 to 600 & 3.1 \\
\hline
\end{tabular}

In addition to these materials, heat pipes, which use phase changes to absorb and reject heat are capable of extremely high effective thermal conductivities (50,000 Watt/m-K) (Ref. 4) to even "several orders of magnitude higher than aluminum or copper" (Ref. 5), and also are candidates for passive cooling plates. Heat pipes are probably the only candidate capable of passively moving the heat for large fuel cells (transmission distances of $\geq 10 \mathrm{~cm})$.

\section{Fabrication of Experimental Cooling Plates}

Samples of fuel cell cooling plate structures were fabricated using HOPG. In addition to these samples, planar heat pipes were fabricated.

\section{Thermal Pyrolytic Graphite (TPG)}

Graphite in general and HOPG in particular consist of a lamellar structure that are composed of stacked planes. These lamellar structures have much stronger forces within the lateral planes than between the planes, thus explaining the characteristic cleaving properties of all of these materials. The pyrolytic graphite used in these experiments was manufactured from thermal decomposition of hydrocarbon gas and is called Thermal Pyrolytic Graphite (TPG). The TPG was obtained from General Electric Advanced Ceramics (Ref. 6) in the form of thin $(0.38 \mathrm{~mm})$ planar sheets. In Table 2 are the technical specifications published by GE Advanced Ceramics.

TABLE 2.-THERMAL PYROLYTIC GRAPHITE MANUFACTURERS SPECIFICATIONS

\begin{tabular}{|l|c|c|}
\hline \multicolumn{1}{|c|}{ Characteristic } & Unit & Value \\
\hline Thermal conductivity (In-plane) & Watt $/ \mathrm{m}-\mathrm{K}$ & 1500 \\
\hline Thermal conductivity (Thru-plane) & Watt $/ \mathrm{m}-\mathrm{K}$ & $<20$ \\
\hline Density & $\mathrm{Gram} / \mathrm{cm}^{3}$ & 2.26 \\
\hline Tensile strength & $\mathrm{MPa}$ & Nil \\
\hline Compressive strength & $\mathrm{MPa}$ & Nil \\
\hline
\end{tabular}

The TPG has little to no mechanical strength. It has very little abrasion resistance and also the surface is too rough for gas tight sealing within a fuel cell stack. Metal/TPG composite structures were fabricated that had improved strength, abrasion resistance and surface roughness characteristics. 
A diffusion bonded Steel/TPG composite cooling plate was fabricated by GE Advanced Ceramics. To make this sample, a thin TPG sheet $(0.38 \mathrm{~mm})$ was diffusion bonded on both sides to 1040 steel. The resultant diffusion bonded part was subsequently surface ground as thin as possible. Difficulty with this process prevented the fabrication of as thin a cooling plate as was desired, and the thickness of these plates still consisted of $2 / 3$ steel and $1 / 3$ TPG. These plates were the thickest plates tested, had the highest density, and on a percentage basis contained the least TPG material. The plates were very stiff, and had a very smooth surface (no quantified measures of these characteristics were made).

A 316SS/TPG composite cooling plate was fabricated at the Glenn Research Center. To make this sample, thin TPG sheets $(0.38 \mathrm{~mm})$ were laminated with $0.05 \mathrm{~mm}$ thick 316SS foils using a hot melt polyester film adhesive at 125 to $135^{\circ} \mathrm{C}$. This technique also produced very stiff plates with a very smooth surface, but were about half the thickness of the diffusion bonded cooling plates. More than half of the overall thickness of the cooling plate was from the TPG.

Copper/TPG composite cooling plates were fabricated at the Glenn Research Center. To make these samples, thin TPG sheets $(0.38 \mathrm{~mm})$ were also laminated with $0.05 \mathrm{~mm}$ thick copper foils using two different electrically conductive adhesives, one adhesive designated as ATTA-LM2 and another adhesive designated as TP1. The electrically conductive adhesives were used to ensure an electrically conductive as well as thermally conductive cooling plate since the cooling plates will also need to conduct electricity between fuel cells. Both electrically conductive adhesives were obtained from Btech Corporation (Ref. 7). Table 3 listed some of the manufacturers published characteristics of these adhesives. Figure 5 shows the TPG cooling plate test samples that were tested.

TABLE 3.-BTECH CORPORATION (REF. 7) ELECTRICALLY CONDUCTIVE ADHESIVES

\begin{tabular}{|l|c|c|c|}
\hline & Unit & ATTA-LM2 & TP1 \\
\hline Thermal conductivity & Watt $/ \mathrm{m}-\mathrm{K}$ & 750 & 5 \\
\hline Electrical resistivity & Ohm-cm & 9.8 & $<10^{-6}$ \\
\hline Tensile modulus & $\mathrm{GPa}$ & 0.03 to 0.09 & 0.06 \\
\hline
\end{tabular}

\begin{tabular}{|l|l|}
\hline \multicolumn{2}{|l|}{ Pyrolytic Graphite (PG) } \\
\hline Length, mm & 100.0 \\
\hline Width, mm & 100.0 \\
\hline Thickness, mm & 0.38 \\
\hline Volume, cm3 & 3.81 \\
\hline Mass, grams & 7.73 \\
\hline Density,g/cc & 2.03 \\
\hline
\end{tabular}
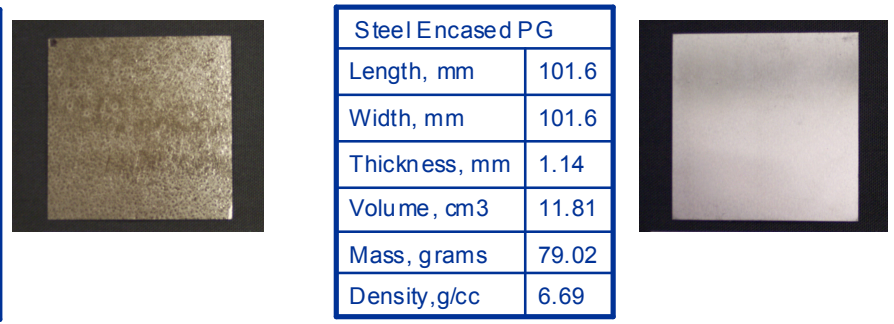

\begin{tabular}{|l|l|}
\hline \multicolumn{2}{|l|}{ SS Laminated PG } \\
\hline Adhesive & Polyester \\
\hline Length, $\mathrm{mm}$ & 102.3 \\
\hline Width, $\mathrm{mm}$ & 102.2 \\
\hline Thickness, mm & 0.61 \\
\hline Volume, cm3 & 6.37 \\
\hline Mass, grams & 17.97 \\
\hline Density, g/cc & 2.82 \\
\hline
\end{tabular}

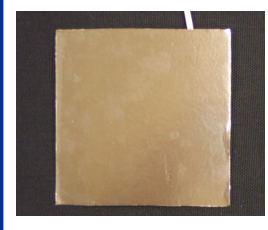

\begin{tabular}{|l|l|l|}
\hline \multicolumn{3}{|l|}{ Cu Laminated PG } \\
\hline Adhesive & ATTA & TP-1 \\
\hline Leng th, mm & 66.0 & 102.0 \\
\hline Width, mm & 74.6 & 102.2 \\
\hline Thickness, mm & 0.66 & 0.66 \\
\hline Volume, cm3 & 3.25 & 6.88 \\
\hline Mass, grams & 8.84 & 23.98 \\
\hline Density, g/cc & 2.72 & 3.48 \\
\hline
\end{tabular}

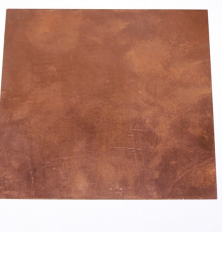

Figure 5.-Thermal pyrolytic graphite cooling plate test samples. 


\begin{tabular}{|l|l|}
\hline \multicolumn{2}{|l|}{ Cu Planar Heat Pipe } \\
\hline Length, mm & 102.1 \\
\hline Width, mm & 102.0 \\
\hline Thickness, mm & 2.01 \\
\hline Volume, cm3 & 20.9 \\
\hline Mass, grams & 81.9 \\
\hline Density, g/cc & 3.92 \\
\hline
\end{tabular}

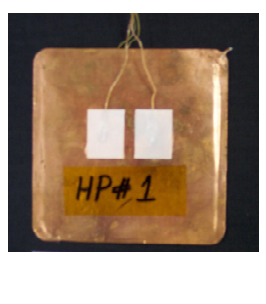

\begin{tabular}{|l|l|}
\hline \multicolumn{2}{|l|}{ Ti Planar Heat Pipe } \\
\hline Length, mm & 95.5 \\
\hline Width, mm & 95.5 \\
\hline Thickness, mm & 1.19 \\
\hline Volume, cm3 & 10.9 \\
\hline Mass, grams & 27.9 \\
\hline Density, g/cc & 2.56 \\
\hline
\end{tabular}

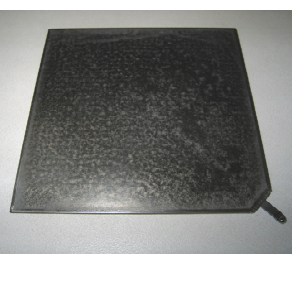

Figure 6.-Heat pipe cooling plate test samples.

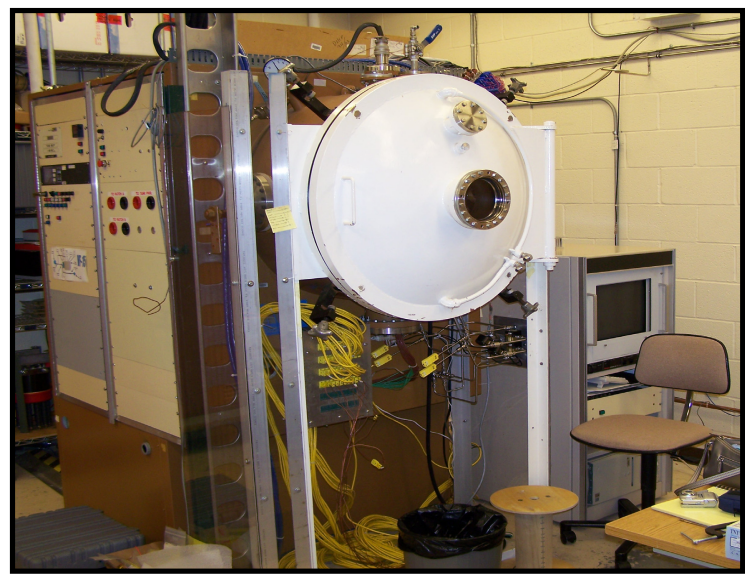

Figure 7.-Cooling plate vacuum test chamber.

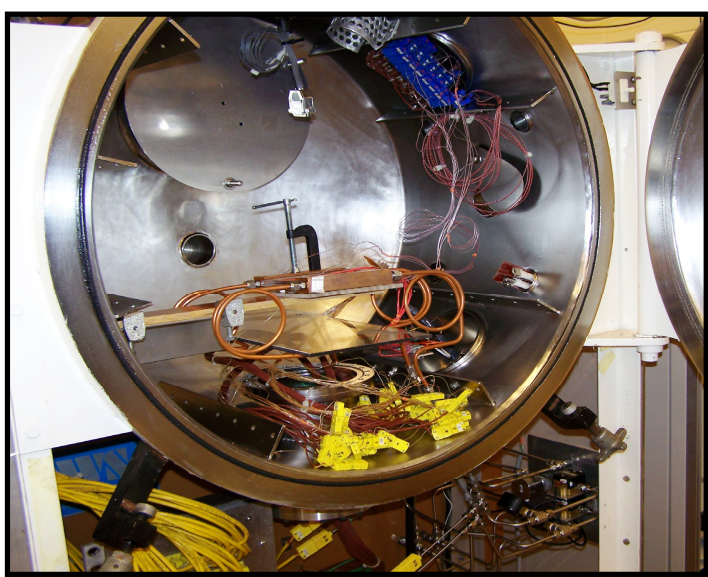

Figure 8.-Cooling plate vacuum test chamber interior.

\section{Planar Heat Pipes}

Heat pipes are another possible approach to a high thermal conductance, low density fuel cell cooling plate. As the name, heat pipe implies, the geometry of heat pipes has been tubular. This geometry is not amenable to integration with a fuel cell stack which consists of planar shapes. Thermacore, Inc. (Ref. 8) was contracted with to develop prototype planar heat pipes. The first planar heat pipe produced was of an all copper construction. A second effort to produce a thinner and lighter prototype produced an all titanium planar heat pipe. Figure 6 shows the planar heat pipes tested, and some basic geometry and mass characteristics.

\section{Cooling Plate Testing}

The cooling plate testing consisted of applying a known heat rate at one edge of each plate and removing the heat from the opposite edge of each plate. Temperature measurements made on the face of each plate gave a measure of the overall plate temperature and the temperature gradient that developed between the hot and cold edges of the plates. These measurements allowed the cooling plate thermal conductivity to be determined.

\section{Cooling Plate Testing Facilities}

The cooling plates were tested in a vacuum chamber shown in Figure 7. The interior of the chamber showing one of the cooling plates and attached instrumentation is shown in Figure 8. Previous attempts to test the samples in an ambient laboratory environment resulted in data that needed corrections to account for convective heat losses. This approach complicated the analysis of the data and was abandoned in favor of testing in vacuum to eliminate convective heat losses. Radiative heat losses from the samples during the test were negligibly small in comparison to the heat being conducted through the plane of the cooling plate. 
Figure 9 illustrates the configuration of the cooling plate test article. Two copper bars containing heater elements were clamped around one edge of the cooling plate. Two copper bars containing cooling channels were clamped around the opposite edge of the cooling plate. Thermocouples were placed on both the heating bars and the cooling bars. Thermocouples were also placed on the face of the cooling plate between the heating and cooling bars. Figure 10 shows a top view of a cooling plate test article inside the vacuum chamber.

Cooling lines were run from the test article to a feed through in the vacuum tank wall, and from there to a temperature controlled chiller bath located outside of the vacuum chamber. Power lines from the cartridge heaters were run to a feed through in the vacuum tank wall and from there to a dc power supply located outside of the vacuum chamber. The thermocouples were similarly run to a feed through and from there to a computer to record the temperature data. Figure 11 illustrates the overall cooling plate test rig.

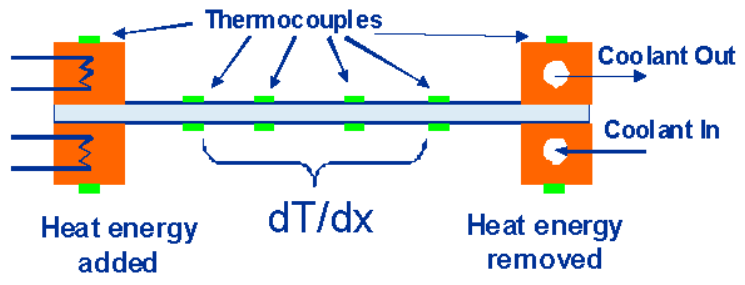

Figure 9.—Cooling plate test article (side view).

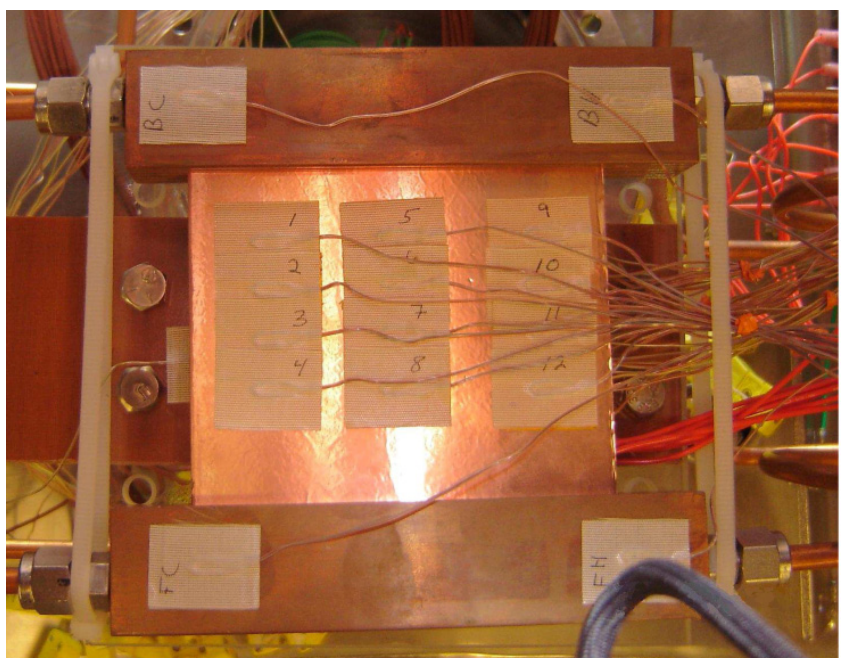

Figure 10.-Cooling plate test article (top view).

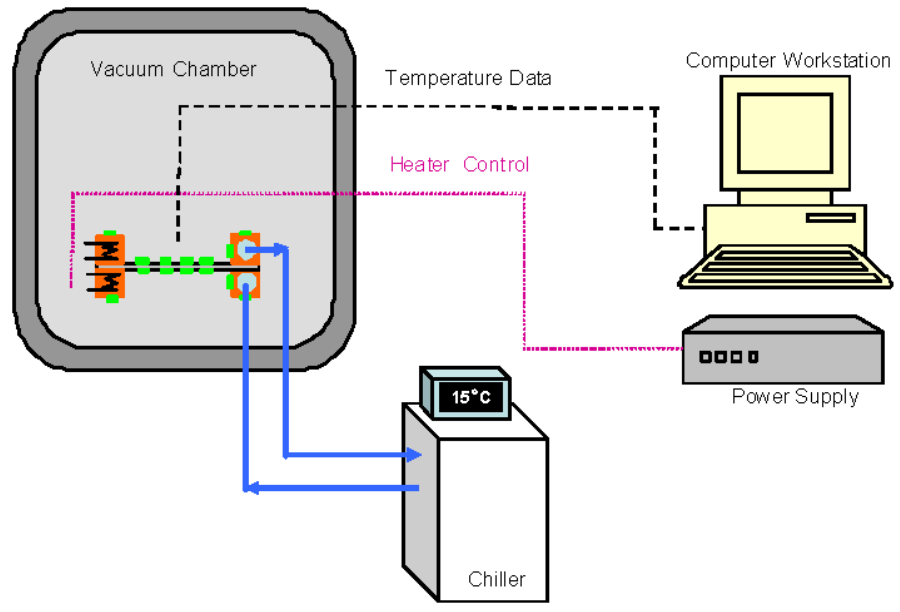

Figure 11.-Cooling plate test rig. 


\section{Cooling Plate Testing Results}

The conducted heat flux Q/A through the plate is proportional to the temperature gradient as shown in Equation (1).

$$
\frac{\mathrm{Q}}{\mathrm{A}}=\mathrm{k} \frac{\mathrm{dT}}{\mathrm{dx}}
$$

Where

Q Applied heat, Watts

A Cooling plate cross sectional area, $\mathrm{m}^{2}$

$\mathrm{k}$ Thermal conductivity, Watt/m-K

$\mathrm{T} \quad$ Cooling plate temperature, $\mathrm{K}$

$\mathrm{x} \quad$ Location of the temperature measurement on the cooling plate, $\mathrm{m}$

$\mathrm{dT} / \mathrm{dx}$ Temperature gradient, $\mathrm{K} / \mathrm{m}$

The temperature data was recorded for a given power applied to the cartridge heaters. The power level was then changed, the temperatures allowed to come to steady state, and another set of temperatures recorded. The temperatures were plotted versus locations on the cooling plate, and the temperature gradient determined. The heat flux at each power level was determined by dividing the applied power by the cooling plate cross sectional area. The heat flux was then plotted versus the temperature gradient determined at each power level. The best fit slope of the line through the data was taken as the thermal conductivity. Table 4 lists all of the test samples that were tested.

TABLE 4.-COOLING PLATE TEST SAMPLES

\begin{tabular}{|l|c|l|}
\hline \multicolumn{1}{|c|}{ Test sample } & Characteristics & Test results \\
\hline $316 \mathrm{SS}$ & 108 by 114 by $1.85 \mathrm{~mm}$ & See Figures 12 and 13 \\
\hline Diffusion bonded TPG & See Figure 5 & See Figures 14 and 15 \\
\hline Copper & 113.5 by 114.8 by $0.89 \mathrm{~mm}$ & See Figures 16 and 17 \\
\hline 316 SS Clad TPG & See Figure 5 & See Figures 18 and 19 \\
\hline Copper clad TPG TP1 & See Figure 5 & See Figures 20 and 21 \\
\hline Copper clad TPG ATTA $\perp$ & See Figure 5 & See Figures 22 and 23 \\
\hline Copper clad TPG ATTA // & See Figure 5 & See Figures 24 and 25 \\
\hline TPG & See Figure 5 & See Figures 26 and 27 \\
\hline Copper planar heat pipe & See Figure 6 & See Figures 28 and 29 \\
\hline Titanium planar heat pipe & See Figure 6 & See Figures 30 and 31 \\
\hline
\end{tabular}

A 316 stainless steel plate was tested because it is a commonly used metal in fuel cell stacks, and also because it had a published value for the thermal conductivity. Figure 12 plots the temperature data collected on a 316 stainless steel plate. Figure 13 plots the heat flux through the stainless steel plate against the temperature gradients determined from Figure 12. The slope of the line in Figure 13 is $28 \mathrm{Watt} / \mathrm{m}-\mathrm{K}$ which is a higher thermal conductivity than its published value of $10 \mathrm{Watt} / \mathrm{m}-\mathrm{K}$. The inaccuracy of the measurement may be due to the limited number of power levels.

A diffusion bonded TPG/steel composite cooling plate was tested. Figure 14 plots the temperature data collected on the diffusion bonded plate. Figure 15 plots the heat flux through the composite plate against the temperature gradients determined from Figure 14. The slope of the line in Figure 15 is $250 \mathrm{Watt} / \mathrm{m}-\mathrm{K}$ which is a thermal conductivity much higher than ordinary steel. This demonstrates the ability of TPG to dramatically improve the thermal conductivity of a low conductance material. Despite this improvement, the conductance of this material is still much too below $1000 \mathrm{Watt} / \mathrm{m}-\mathrm{K}$ to be suitable for a fuel cell cooling plate.

A copper plate was tested because it was a material with a high thermal conductivity that was known and could serve to check our test methodology. Figure 16 plots the temperature data collected on the copper plate. Figure 17 plots the heat flux through the copper plate against the temperature gradients determined from Figure 16. The slope of the line in Figure 17 is 405 Watt/m-K which is close to copper's published thermal conductivity of 395 Watt/ $\mathrm{m}-\mathrm{K}$. This is still too low of a thermal conductance to be suitable as a cooling plate. 


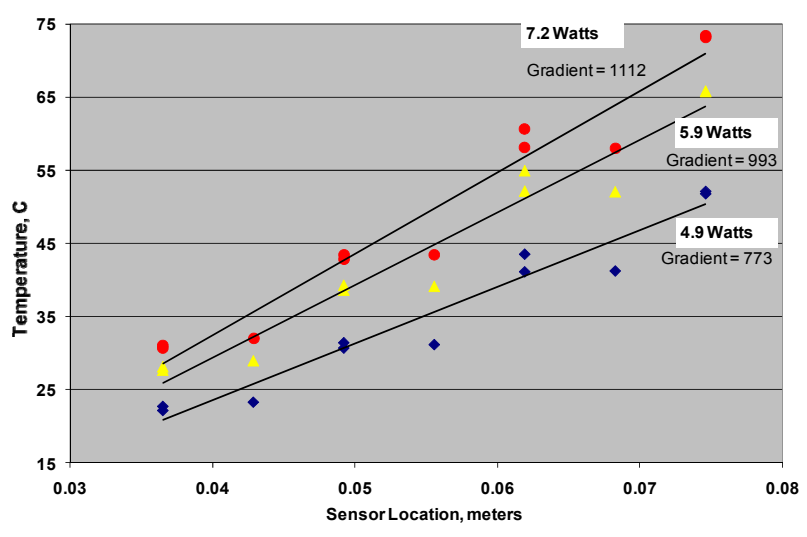

Figure 12.-316SS temperature gradient.

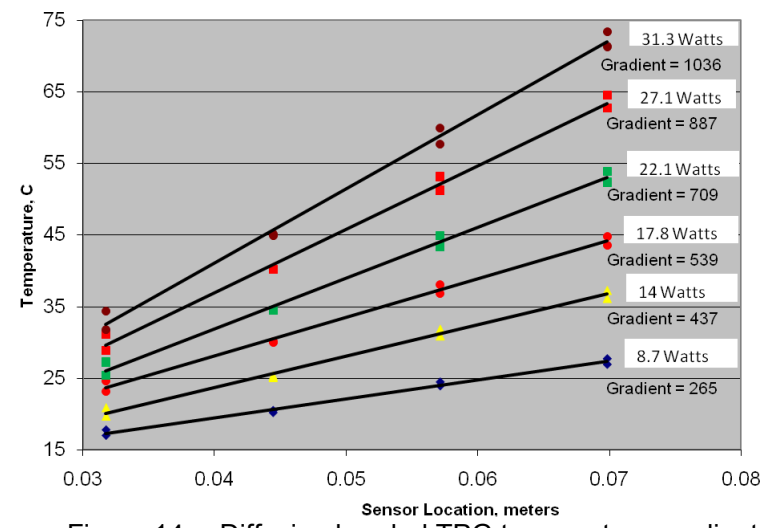

Figure 14.-Diffusion bonded TPG temperature gradient.

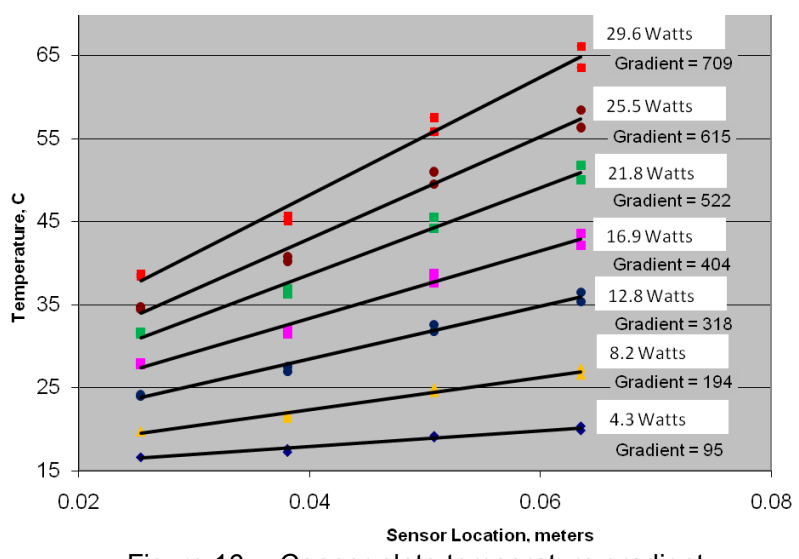

Figure 16.—Copper plate temperature gradient.

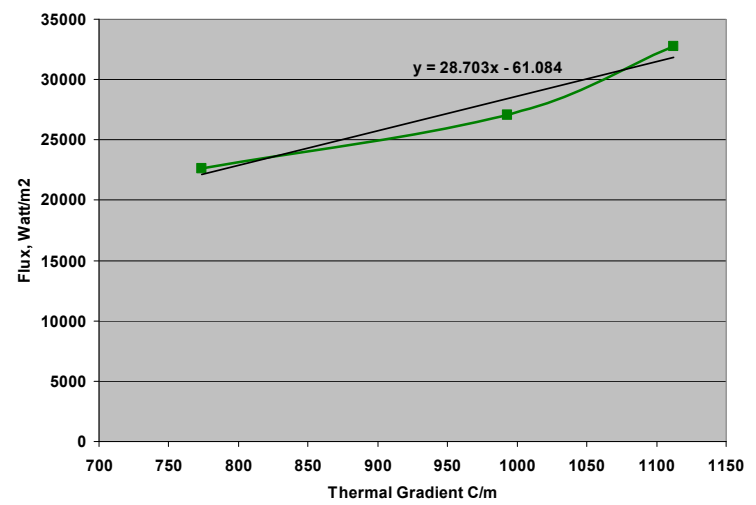

Figure 13.-316SS temperature conductivity.

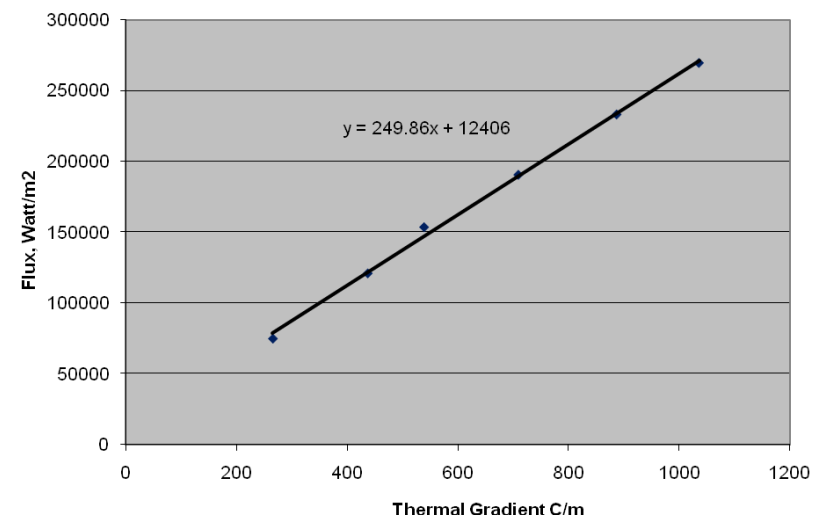

Figure 15.-Diffusion bonded TPG thermal conductivity.

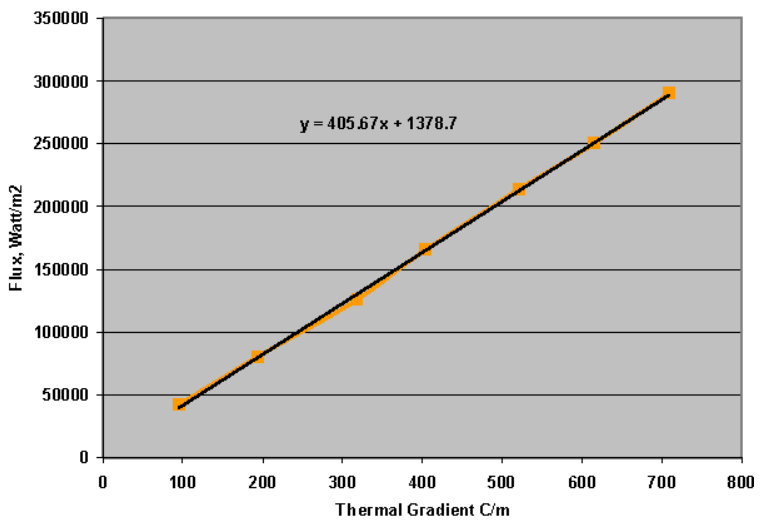

Figure 17.-Copper plate thermal conductivity. 
A 316 stainless steel clad TPG composite cooling plate was tested. Figure 18 plots the temperature data collected on the stainless steel clad cooling plate. Figure 19 plots the heat flux through the composite plate against the temperature gradients determined from Figure 18. The slope of the line in Figure 19 is $962 \mathrm{Watt} / \mathrm{m}-\mathrm{K}$ which is a thermal conductivity much higher than that measured for the pure stainless steel plate. This again demonstrates the ability of TPG to dramatically improve the thermal conductivity of a low conductance material. This improvement is sufficient to be an acceptable material for a fuel cell cooling plate where the heat does not have to be transmitted across the active area of a fuel cell more than 4 to $5 \mathrm{~cm}$.

A copper clad TPG composite cooling plate was tested. This composite plate was made with the TP1 electrically conductive adhesive. Figure 20 plots the temperature data collected on the copper clad cooling plate. Figure 21 plots the heat flux through the composite plate against the temperature gradients determined from Figure 20.

The slope of the line in Figure 21 is $1105 \mathrm{Watt} / \mathrm{m}-\mathrm{K}$ which is a thermal conductivity much higher than that measured for the pure copper plate. This again demonstrates the ability of TPG to dramatically improve the thermal conductivity of even a high conductance material like copper. This improvement is sufficient to be an acceptable material for a fuel cell cooling plate where the heat does not have to be transmitted across the active area of a fuel cell more than 4 to $5 \mathrm{~cm}$.

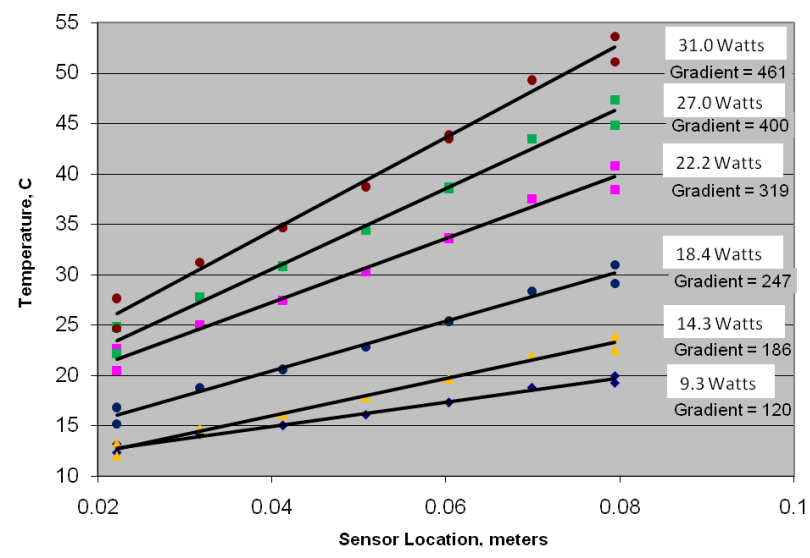

Figure 18._-316SS clad TPG temperature gradient.

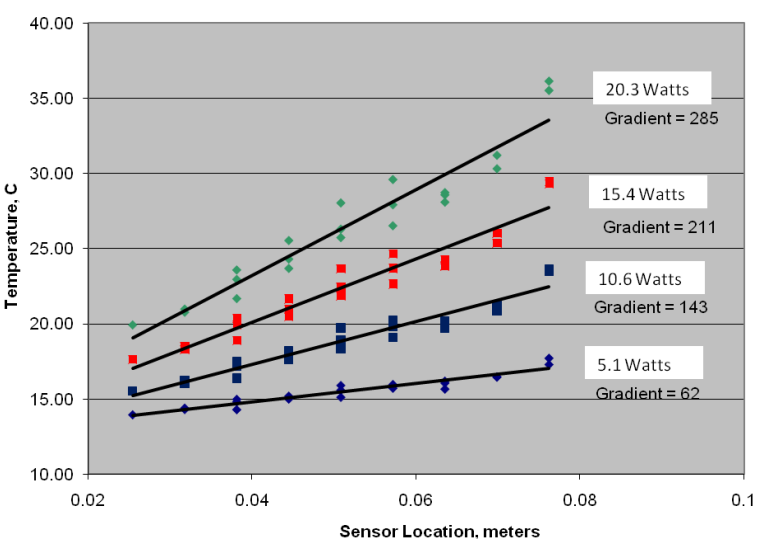

Figure 20.-Cu clad TPG TP1 temperature gradient.

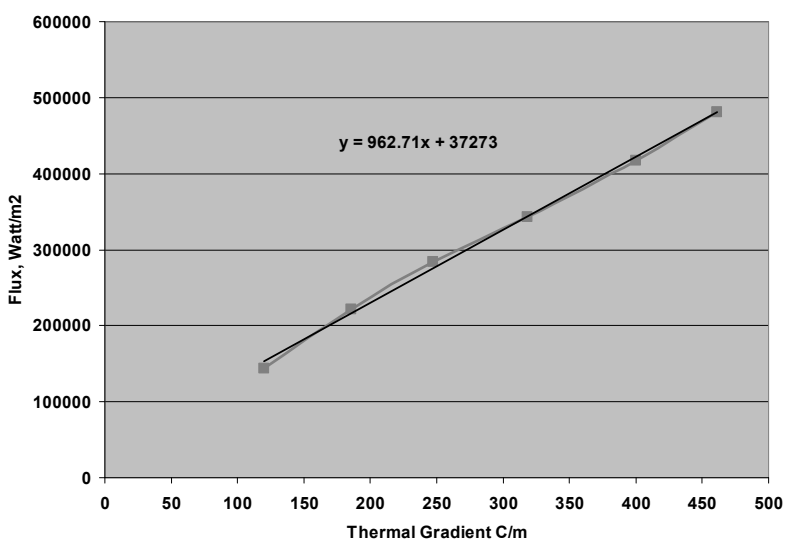

Figure 19._-316SS clad TPG thermo conductivity.

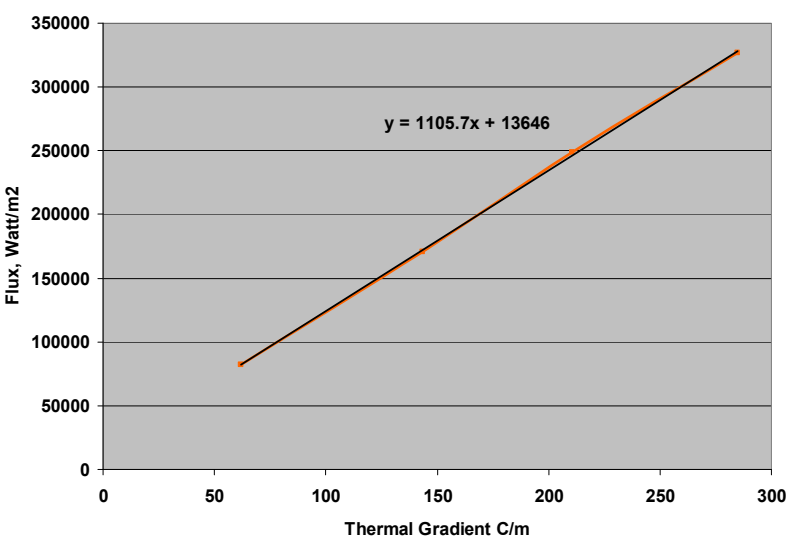

Figure 21.-Cu clad TPG TP1 thermal conductivity. 
Another copper clad TPG composite cooling plate was tested. This composite plate was made with the ATTA-LM2 electrically conductive adhesive. The ATTA adhesive has a greater thermal conductivity in one inplane direction than the other in-plane direction. For this sample the higher conductivity direction was oriented perpendicular to the heat flux direction. Figure 22 plots the temperature data collected on the copper clad cooling plate.

Figure 23 plots the heat flux through the composite plate against the temperature gradients determined from Figure 22. The slope of the line in Figure 23 is $1149 \mathrm{Watt} / \mathrm{m}-\mathrm{K}$ which is a thermal conductivity much higher than that measured for the pure copper plate. This copper clad composite plate had a lower density than the copper clad plate made with the TP1 adhesive. The lower density and the high thermal conductance makes this composite plate an acceptable material for a fuel cell cooling plate where the heat does not have to be transmitted across the active area of a fuel cell more than 5 to $6 \mathrm{~cm}$.

Another copper clad TPG composite cooling plate was tested. This composite plate was also made with the ATTA-LM2 electrically conductive adhesive, but this sample was tested with the higher conductivity direction oriented parallel to the heat flux direction. Figure 24 plots the temperature data collected on the copper clad cooling plate. Figure 25 plots the heat flux through the composite plate against the temperature gradients determined from Figure 24. The slope of the line in Figure 25 is $1167 \mathrm{Watt} / \mathrm{m}-\mathrm{K}$ which is a thermal conductivity slightly higher than that measured for the other composite plate made with the ATTA adhesive oriented in the perpendicular direction. This copper clad composite plate had a lower density than the copper clad plate made with the TP1 adhesive.

The lower density and the high thermal conductance makes this composite plate an acceptable material for a fuel cell cooling plate where the heat does not have to be transmitted across the active area of a fuel cell more than 5 to $6 \mathrm{~cm}$.

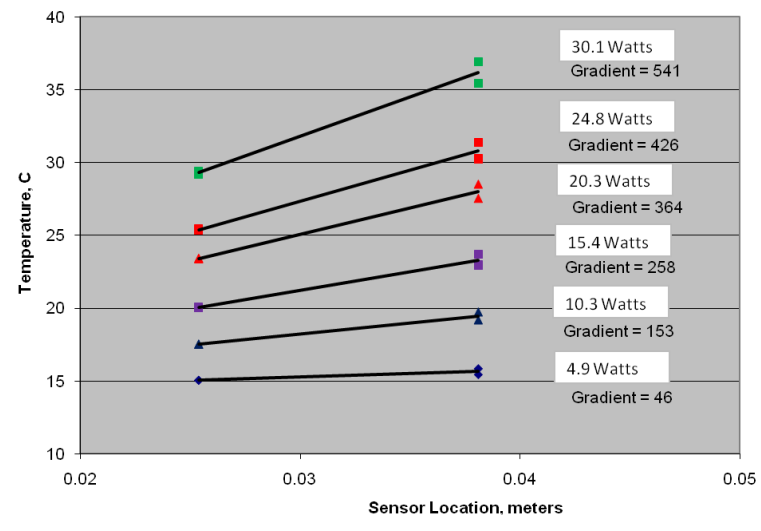

Figure 22.-Cu clad TPG ATTA $\perp$ temperature gradient.

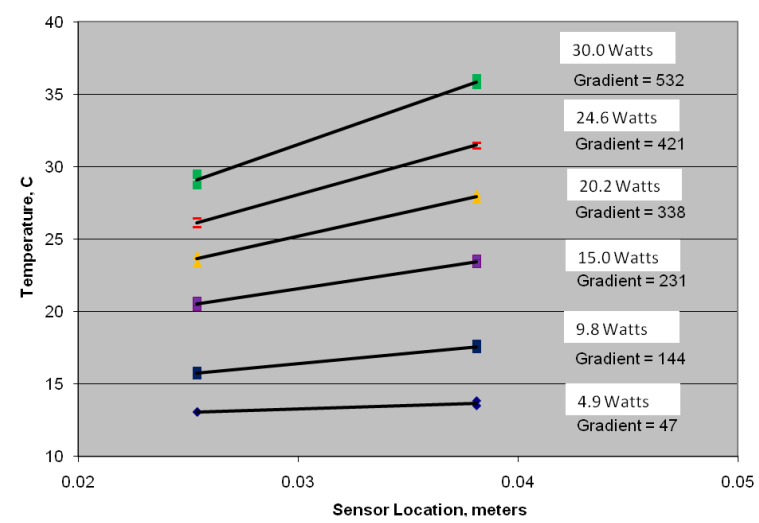

Figure 24.-Cu clad TPG ATTA // temperature gradient.

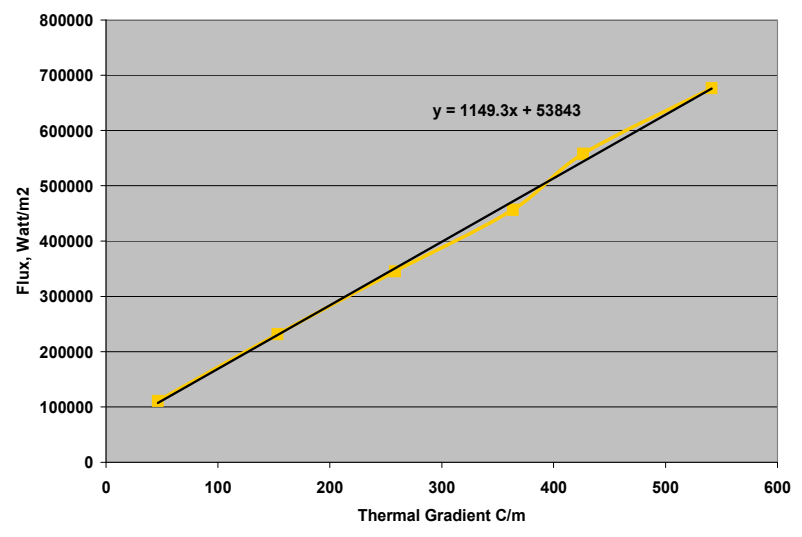

Figure 23. - C Cu clad TPG ATTA $\perp$ thermal conductivity.

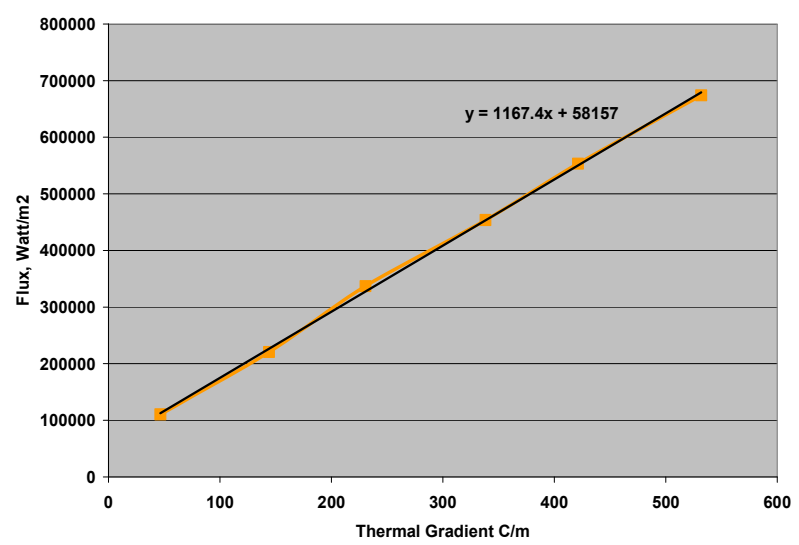

Figure 25.-Cu clad TPG ATTA // thermal conductivity. 
The unaltered TPG was tested. The thermal conductivity was measured to compare with the manufacturers published value and to help validate our testing apparatus. The measurement also served as a comparison to the various metal/TPG composites that were fabricated and tested. Figure 26 plots the temperature data collected on the TPG plate. Figure 27 plots the heat flux through the composite plate against the temperature gradients determined from Figure 26. The slope of the line in Figure 27 is $1426 \mathrm{Watt} / \mathrm{m}-\mathrm{K}$ which falls only 5 percent lower than the value published by the manufacturer. The composites made with the TPG had thermal conductivity ranging from 962 to $1167 \mathrm{Watt} / \mathrm{m}-\mathrm{K}$. The lower values represent the penalty for upgrading the undesirable characteristics of the TPG.

A copper planar heat pipe from Thermacore, Inc. (Ref. 8) was tested. This heat pipe was Thermacore's first attempt to produce a heat pipe with a thin planar geometry. The design of the planar heat pipe drew from Thermacore's experience in producing tubular copper heat pipes. Figure 28 plots the temperature data collected on the copper planar heat pipe plate. Figure 29 plots the heat flux through the heat pipe plate against the temperature gradients determined from Figure 28. The slope of the line in Figure 29 is $14050 \mathrm{Watt} / \mathrm{m}-\mathrm{K}$. This is an order of magnitude higher than any of the other cooling plate prototypes tested, and represents a major leap in thermal conductance. The data plotted in Figure 29 does not fit a linear relationship, but shows an increasing conductance as the heat flux and temperature gradient increase. The two-phase heat transfer mechanism in the heat pipe involves boiling the internal fluid at one location on the heat pipe plate and condensing the same internal fluid at another location on the heat pipe plate. This heat transfer behavior is fundamentally different than conductive heat transfer. As more heat is applied to the heat pipe, the boiling rate, hence the production of vapor inside the heat pipe increases. Because the interior space of the heat pipe is constant, the speed of the vapor movement inside the heat pipe increases. As the vapor transport speed increases, the thermal gradient across the heat pipe increases at slower rate, and can actually get smaller with increasing heat flux (i.e., a negative slope). Despite the extraordinary thermal conductivity, the thickness and mass of this heat pipe limits its utility for cooling in fuel cells.

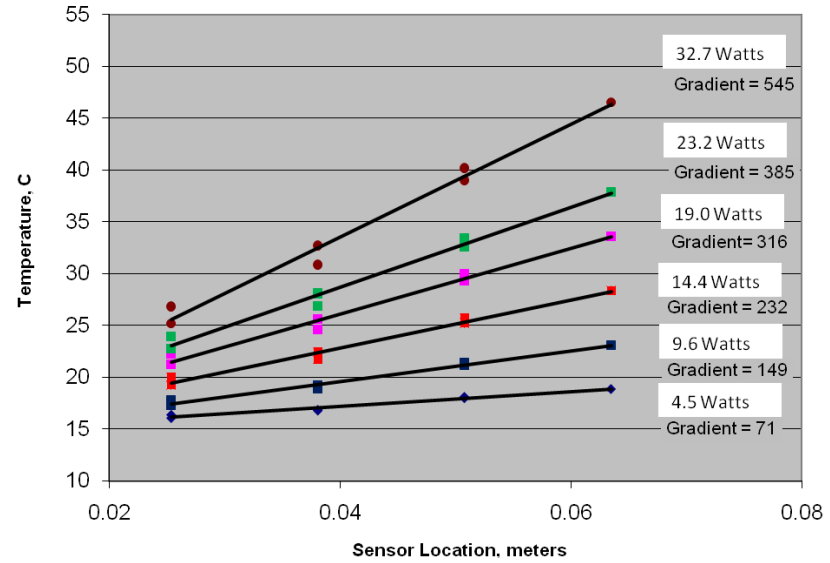

Figure 26.-TPG temperature gradient.

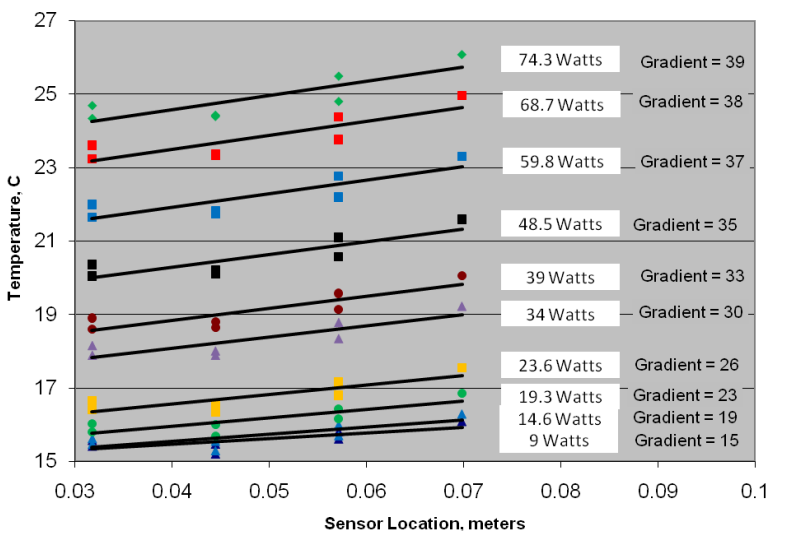

Figure 28.-Copper heat pipe temperature gradient.

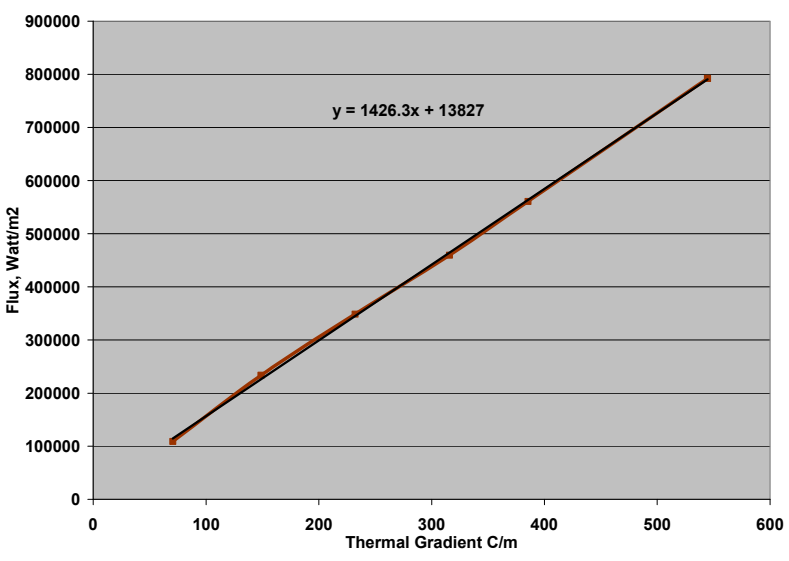

Figure 27._-TPG thermal conductivity gradient.

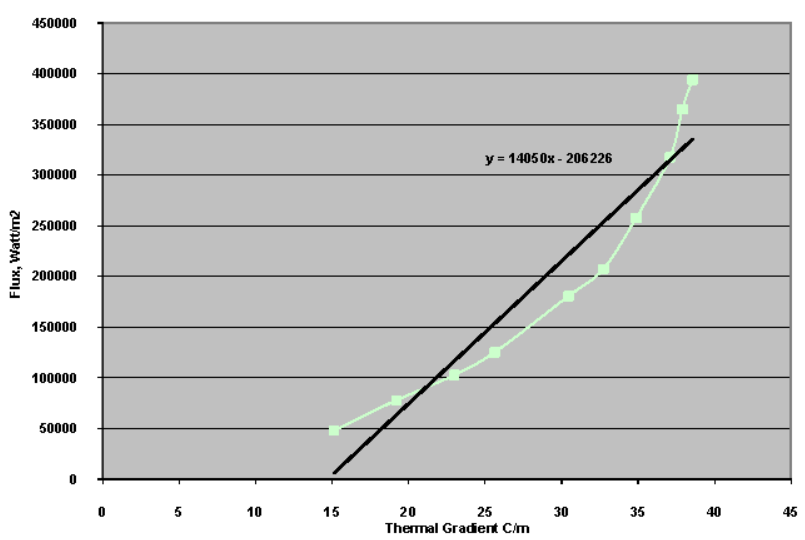

Figure 29.-Copper heat pipe thermal conductivity. 
A titanium planar heat pipe from Thermacore, Inc. (Ref. 8) was also tested. This heat pipe was Thermacore's second attempt to produce a heat pipe with a thin planar geometry. The choice of titanium was to reduce the mass of a planar heat pipe. The titanium metal is much lighter than copper, and its greater strength would allow the planar heat pipe to be made thinner as well. Thermacore, Inc. had some experience producing tubular titanium heat pipes, and drew on this experience to design and fabricate the planar titanium heat pipe. Figure 30 plots the temperature data collected on the titanium planar heat pipe plate. Figure 31 plots the heat flux through the heat pipe plate against the temperature gradients determined from Figure 30. The slope of the line in Figure 31 is $-20447 \mathrm{Watt} / \mathrm{m}-\mathrm{K}$. Like the copper heat pipe this is an order of magnitude higher than any of the other cooling plate prototypes tested. The data plotted in Figure 31 does fit a linear relationship, but shows a negative slope, that is a negative thermal conductance. This behavior is obviously very different that the various positive slopes seen with the other cooling plate prototypes, and like the copper heat pipe is because the physics underlying the two phase heat transfer mechanism in the heat pipe is not the same as the physics underlying the solid conduction heat transfer in the other cooling plates tested. This heat pipe has the lowest density of any of the cooling plates tested except for the unaltered TPG. Coupled with the extraordinary thermal conductivity, this heat pipe was clearly the best alternative for a passive fuel cell cooling plate.

Figure 32 shows the thermal conductivity plots of all the plates listed in Table 4. Looking at the plot, the data breaks into three groups, the highest conductivity group which are the heat pipes, the second highest group which are the TPG and TPG laminates, and the final group which is the diffusion bonded TPG and the metals.

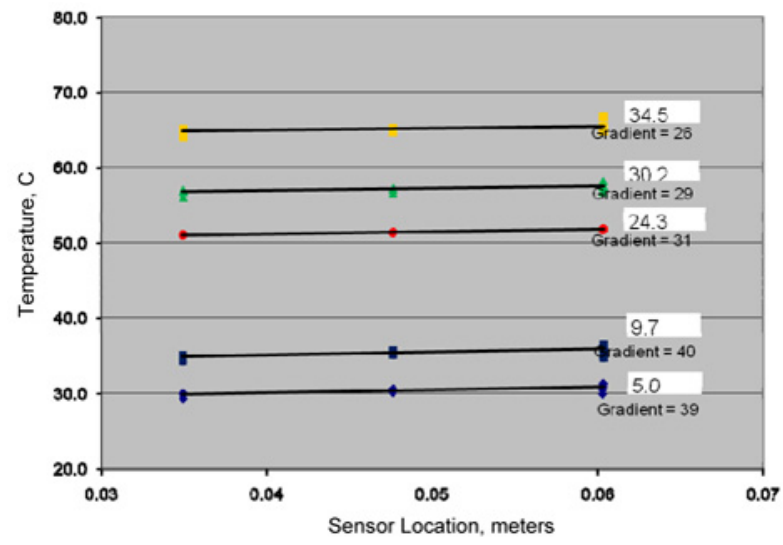

Figure 30.-Titanium heat pipe temperature gradient.

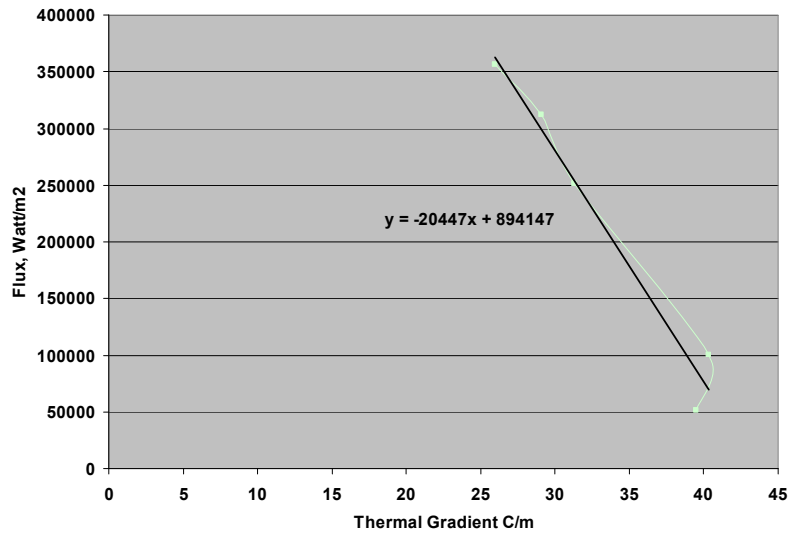

Figure 31.-Titanium heat pipe thermal conductivity.

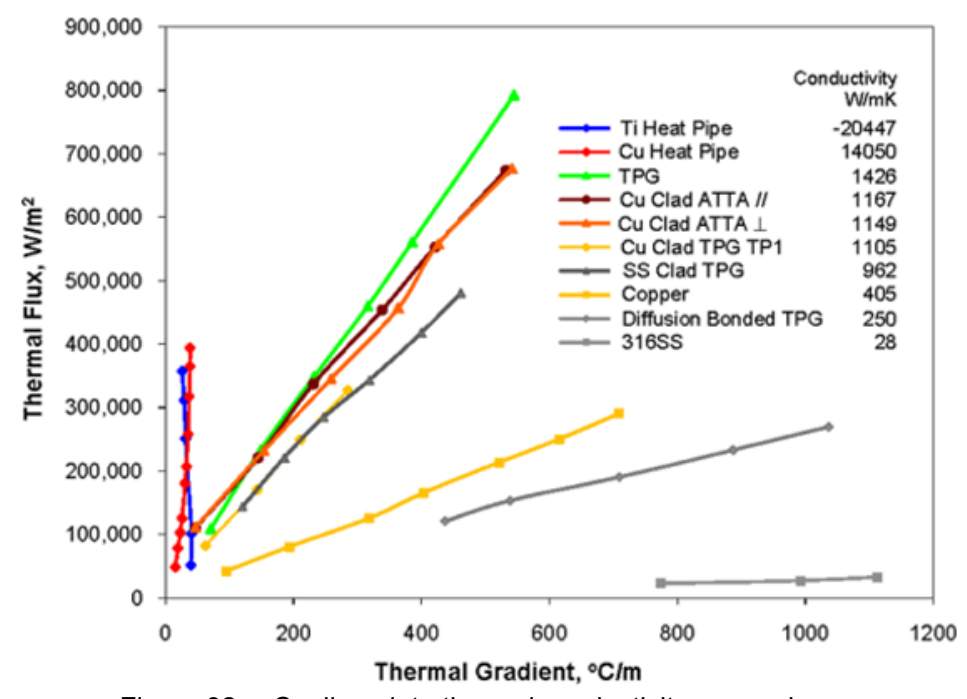

Figure 32.-Cooling plate thermal conductivity comparison. 


\section{Conclusions}

The efforts to develop passive fuel cell thermal management materials has lead to the following conclusions:

1. Passive cooling plates can be fabricated that are capable of meeting the $3{ }^{\circ} \mathrm{C}$ maximum temperature difference and the $1000 \mathrm{Watt} / \mathrm{kg}$ mass target.

2. There are two approaches to the construction of the passive cooling plates, use TPG thin sheets laminated with even thinner metal foils to improve TPG's low mechanical strength. This approach will be satisfactory for smaller fuel cells where the heat transmission distance across the active area of the fuel cell is $6 \mathrm{~cm}$ or less. The second approach is to use planar titanium heat pipes. This approach will be satisfactory for all fuel cell sizes, and will also be lower in mass than the TPG approach.

\section{References}

1. Kenneth A. Burke, "Advanced Fuel Cell System Thermal Management for NASA Exploration Missions," NASA/TM-2008-215426, AIAA-2008-5795, presented at AIAA 6th International Energy Conversion Engineering Conference, July 28-30 2008, Cleveland, Ohio.

2. William E. Simon and Donald L. Nored, "Manned Spacecraft Electrical Power Systems," Proceeding of the IEEE, Vol. 75, No. 3, March 1987.

3. Zweben, Carl "New, Ultrahigh-Thermal-Conductivity Packaging Materials," IEEE Components, Packaging \& Manufacturing Technology Society - Santa Clara Valley Chapter, Sunnyvale, California, March 16, 2005.

4. Geoffrey Thyrum and Ellen Cruse, "Heat Pipe Simulation," Advanced Packaging Magazine, Dec. 2001.

5. The Engineering Handbook, Second Edition, Richard C. Dorf, Editor-in-Chief, CRC Press, 2005.

6. GE Advanced Ceramics, This company was bought and now is Momentive Performance Materials, Inc. 22557 Lunn Road, Strongsville, Ohio 44149 (440) 878-5700.

7. Btech Corporation, 8395 Greenwood Drive, Longmont, Colorado 80503 USA (303) 652-6418.

8. Thermacore, Inc., 780 Eden Road, Lancaster, Pennsylvania 17601 USA (717) 569-6551. 


\begin{tabular}{|c|c|c|}
\hline \multicolumn{2}{|c|}{ REPORT DOCUMENTATION PAGE } & $\begin{array}{l}\text { Form Approved } \\
\text { OMB No. 0704-0188 }\end{array}$ \\
\hline \multicolumn{3}{|c|}{ 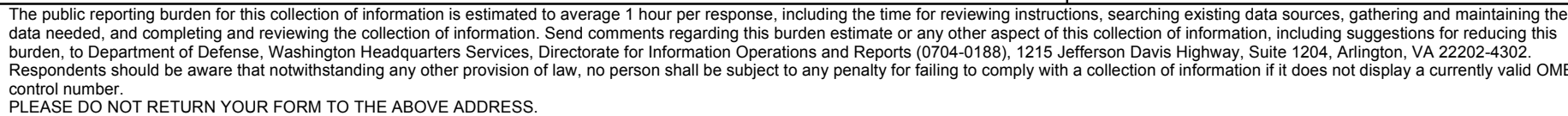 } \\
\hline $\begin{array}{l}\text { 1. REPORT DATE (DD-MM-YYYY) } \\
01-12-2010\end{array}$ & $\begin{array}{l}\text { 2. REPORT TYPE } \\
\text { Technical Memorandum }\end{array}$ & 3. DATES COVERED (From - To) \\
\hline \multirow{3}{*}{\multicolumn{2}{|c|}{$\begin{array}{l}\text { 4. TITLE AND SUBTITLE } \\
\text { Development of Passive Fuel Cell Thermal Management Technolog }\end{array}$}} & 5a. CONTRACT NUMBER \\
\hline & & 5b. GRANT NUMBER \\
\hline & & 5c. PROGRAM ELEMENT NUMBER \\
\hline \multirow{3}{*}{\multicolumn{2}{|c|}{$\begin{array}{l}\text { 6. AUTHOR(S) } \\
\text { Burke, Kenneth, A.; Jakupca, Ian; Colozza, Anthony }\end{array}$}} & 5d. PROJECT NUMBER \\
\hline & & 5e. TASK NUMBER \\
\hline & & \begin{tabular}{|l} 
5f. WORK UNIT NUMBER \\
WBS 038957.04.06.02.02.03
\end{tabular} \\
\hline \multicolumn{2}{|c|}{$\begin{array}{l}\text { 7. PERFORMING ORGANIZATION NAME(S) AND ADDRESS(ES) } \\
\text { National Aeronautics and Space Administration } \\
\text { John H. Glenn Research Center at Lewis Field } \\
\text { Cleveland, Ohio 44135-3191 }\end{array}$} & $\begin{array}{l}\text { 8. PERFORMING ORGANIZATION } \\
\text { REPORT NUMBER } \\
\text { E-17399 }\end{array}$ \\
\hline \multirow{2}{*}{\multicolumn{2}{|c|}{$\begin{array}{l}\text { 9. SPONSORING/MONITORING AGENCY NAME(S) AND ADDRESS(ES) } \\
\text { National Aeronautics and Space Administration } \\
\text { Washington, DC 20546-0001 }\end{array}$}} & $\begin{array}{l}\text { 10. SPONSORING/MONITOR'S } \\
\text { ACRONYM(S) } \\
\text { NASA }\end{array}$ \\
\hline & & $\begin{array}{l}\text { 11. SPONSORING/MONITORING } \\
\text { REPORT NUMBER } \\
\text { NASA/TM-2010-216773 }\end{array}$ \\
\hline \multicolumn{3}{|c|}{$\begin{array}{l}\text { 12. DISTRIBUTION/AVAILABILITY STATEMENT } \\
\text { Unclassified-Unlimited } \\
\text { Subject Categories: } 20 \text { and } 44 \\
\text { Available electronically at } h t t p: / / g l t r s . g r c . n a s a . g o v \\
\text { This publication is available from the NASA Center for AeroSpace Information, 443-757-5802 }\end{array}$} \\
\hline
\end{tabular}

\section{SUPPLEMENTARY NOTES}

\section{ABSTRACT}

The NASA Glenn Research Center is developing advanced passive thermal management technology to reduce the mass and improve the reliability of space fuel cell systems for the NASA exploration program. The passive thermal management system relies on heat conduction within the cooling plate to move the heat from the central portion of the cell stack out to the edges of the fuel cell stack rather than using a pumped loop cooling system to convectively remove the heat. Using the passive approach eliminates the need for a coolant pump and other cooling loop components which reduces fuel cell system mass and improves overall system reliability. Previous analysis had identified that low density, ultra-high thermal conductivity materials would be needed for the cooling plates in order to achieve the desired reductions in mass and the highly uniform thermal heat sink for each cell within a fuel cell stack. A pyrolytic graphite material was identified and fabricated into a thin plate using different methods. Also a development project with Thermacore, Inc. resulted in a planar heat pipe. Thermal conductivity tests were done using these materials. The results indicated that lightweight passive fuel cell cooling is feasible. 15. SUBJECT TERMS

Fuel cells; Cooling; Temperature control; Cooling systems; Thermal conductivity

\begin{tabular}{|c|c|c|c|c|c|}
\hline \multicolumn{3}{|c|}{ 16. SECURITY CLASSIFICATION OF: } & \multirow{2}{*}{$\begin{array}{l}\text { 17. LIMITATION OF } \\
\text { ABSTRACT } \\
\text { UU }\end{array}$} & \multirow{2}{*}{$\begin{array}{l}\text { 18. NUMBER } \\
\text { OF } \\
\text { PAGES } \\
20\end{array}$} & \multirow{2}{*}{$\begin{array}{l}\text { 19a. NAME OF RESPONSIBLE PERSON } \\
\text { STI Help Desk (email:help@sti.nasa.gov) } \\
\text { 19b. TELEPHONE NUMBER (include area code) } \\
\text { 443-757-5802 }\end{array}$} \\
\hline $\begin{array}{l}\text { a. REPORT } \\
U\end{array}$ & $\begin{array}{l}\text { b. ABSTRACT } \\
U\end{array}$ & $\begin{array}{l}\text { c. THIS } \\
\text { PAGE } \\
\text { U }\end{array}$ & & & \\
\hline
\end{tabular}



